\title{
The Housing Boom and Forest Fires
}

\author{
Libertad González * \\ Universitat Pompeu Fabra
}

October 2007

\begin{abstract}
This paper provides evidence that the combination of land-use restrictions and an increasing demand for housing can create incentives to induce forest fires as a means to circumvent regulation and increase the supply of land available for residential construction. I estimate the effect of the price of housing on the incidence of forest fires using Spanish data by region for 1991-2005. The results suggest that higher house prices led to a significant increase in the incidence of forest fires in a region. I also find that the increased incidence of forest fires led to a subsequent reduction in forest area and an increase in urban land area. This evidence supports the claims often found in the media that property speculators trying to build in forest land may be behind the recent increases in the incidence of forest fires in Mediterranean countries.
\end{abstract}

Keywords: forest fires, housing prices, land-use change.

JEL Codes: Q15, Q23, R21.

\footnotetext{
* Universitat Pompeu Fabra, Department of Economics and Business, Ramón Trias Fargas 25-27, 08005 Barcelona, Spain. Email: libertad.gonzalez@upf.edu. Phone: (+34) 93542 2610. Fax: (+34) 935421746.

- I thank Ignacio Vergara Gasulla for his excellent assistance with data collection, and I acknowledge grant SEJ2007-64340 for financial support. The paper has benefited from useful comments by the participants in the Applied Lunch Seminar at Universitat Pompeu Fabra and two anonymous referees.
} 


\section{Introduction}

A sizeable recent literature addresses the relationship between economic growth and environmental quality. ${ }^{1}$ Empirical studies typically use cross-country data to study the reduced-form relationship between per capita income and some measure of environmental quality, typically air (or water) quality. ${ }^{2}$

Economic theory suggests that this relationship is less than straightforward, particularly since different sources of economic growth can lead to different shapes of the relation between growth and the environment. For this reason, Copeland and Taylor (2004) stress the need for empirical studies to clarify the causal mechanisms involved rather than merely document the shape of the association.

The contribution of this study is to shed light on a very specific channel through which economic growth can affect environmental quality. The status of forests is a key environmental indicator in many countries that is rarely analyzed in the literature. An exception is found in Koop and Tole (1999), who analyze the association between per capita income and deforestation, finding some empirical support for a U-shaped relationship between the two.

As mentioned, Copeland and Taylor (2004) suggest empirical studies should move from merely documenting the reduced-form shape of such a relationship to uncovering the causal mechanisms at work. In this line, this study focuses on a very specific mechanism that can lead to a relationship between economic growth and deforestation. Certain sources of economic growth can induce pressures to increase the supply of available land, for instance

\footnotetext{
${ }^{1}$ See Copeland and Taylor, 2004 for a recent survey.

${ }^{2}$ See Grossman and Krueger, 1995 and Shafik, 1994 for some of the earlier studies.
} 
for residential construction purposes. This pressure can in turn lead to changes in the regulation of the use of land. However, in some countries the possibility to build in forested areas is heavily restricted.

One way in which such regulations can be circumvented is the event of a wildfire that drastically reduces the environmental value of a forest, thus easing restrictions and allowing more (formerly forested) land to be freed for building activity. In fact, the media as well as environmental organizations in different countries have often raised concerns about arson by property speculators trying to build on forest land. This study is, to my knowledge, the first to empirically investigate the relevance of such claims. If the evidence supports them, as I show, then there are clear policy implications to be derived. Land use regulations should be designed taking into consideration the incentives they may generate regarding the potential induction of forest fires. For instance, some countries (such as Greece) restrict changes in the use of land for a number of years after a forest is affected by wildfire, trying to limit the effectiveness of forest fire as a means to increase the supply of land for building purposes. Additional measures should be taken to ensure that such laws are in fact implemented, since their effectiveness in practice has been questioned. ${ }^{3}$

I use data on forest fires, changes in the use of land and economic activity in Spanish regions over a fifteen-year period (1991 through 2005). The reasons why Spain is an interesting case study are twofold. First, the incidence of forest fires in Spain has increased dramatically over the past few decades, and most of them are thought to be human-induced.

3 "Many Mediterranean states have laws against building on burned forest land (...). Corruption, and weak or clogged legal systems, can undermine such rules, of course." ("Smoke gets in their eyes", The Economist, August $4^{\text {th }} 2007$, p. 28). 
Second, the construction sector experienced an unprecedented boom during the late 1990's, fueled by a soaring demand for housing and generating intense pressure to increase the availability of land for residential construction.

We find that the regions where housing prices were increasing more rapidly (which we take as an indicator of rising demand for housing) experienced a significantly higher incidence of forest fires. The incidence of forest fires, in turn, led to subsequent changes in the use of land, reducing the amount of forest area and increasing urban land area (i.e. land where building activity takes place). We take this evidence as suggesting that economic growth in Spain between 1991 and 2005, which relied heavily on the construction sector, had a direct negative effect on environmental quality through the degradation of the status of forests.

The remainder of the paper is organized as follows. Section 2 presents some background information on land use and the incidence of forest fires in Spain, and it discusses the recent evolution of the construction sector and housing prices. Section 3 describes the data and the econometric methodology, and the results are introduced in section 4. Section 5 summarizes the findings and concludes.

\section{Background: Forest Fires, Use of Land and the Housing Boom in Spain}

\subsection{Forest Fires}

Forest fires destroy millions of acres of wild land around the world every year, and lead to large economic and environmental losses. In 2001, the number of blazes reached 106,692 in Europe and 142,066 in the US and Canada, affecting over 1 million and 5 million acres of wild land, respectively. Federal agencies in the US spent 918 million dollars in fire 
suppression in $2001,{ }^{4}$ but the total environmental and economic costs of forest fires are estimated to be much higher.

In Europe, Spain is the country with the largest land area affected by forest fires in recent years (see table 1), ahead of other Southern European countries with similar weather conditions. Between 1991 and 2004, forest fires affected on average 362,550 acres a year in Spain, or 27 percent of the total land area affected in Europe. Almost 19,500 blazes were reported each year (on average) during that period. The direct yearly economic losses associated with forest fires in Spain were estimated to be 505 million euros in $2005 .^{5}$

Moreover, a worrying trend towards an increasing number of blazes has been observed in Spain in recent decades (see figure 1). In the 1960's, less than 2,000 fires were detected a year, while in 1995 the figure reached almost 26,000. This trend is also reflected in the evolution of the land area affected by forest fires (the yearly average was 118,000 acres in the 1960's, compared with 365,000 between 1994 and 2004).

Not much is known about the causes of the increasing incidence of forest fires in Spain. Estimates from the Spanish Ministry of the Environment indicate that about 60 percent of all forest fires that took place between 1991 and 2004 were intentional, and the origin of the fire is not known in almost 20 percent of the cases. ${ }^{6}$ However, the media as well as environmental organizations routinely report that one important factor behind the high

\footnotetext{
${ }^{4}$ Average suppression costs were 830 million dollars a year during the 1994-2004 period (Wildland Fire Statistics, 2005).

${ }^{5}$ Spanish Ministry of the Environment, 2007 (http://www.mma.es).

${ }^{6}$ The remaining causes are thunder (4\%), negligence (14\%), reproduction of a previous fire (1\%), and other causes (3\%) (http://www.mma.es).
} 
incidence of forest fires is the intended rezoning of forest area (where building activity is banned or severely restricted) into urban land for construction purposes. ${ }^{7}$ Yet, only anecdotal evidence is provided in support of this argument. ${ }^{8}$

\subsection{Land use regulation}

The use of land is heavily regulated in Spain. The general guidelines are outlined in a federal law, which dictates that land can be classified as urban, potentially urban (i.e. where building activity is allowed), and rustic land (where building activity is heavily restricted). The authority to actually classify land into each category lies with the municipalities, although local authority plans need to be approved at the regional or national level and should follow the general guidelines indicated in the federal law. Any building activity in rustic land must be approved at the regional level. In practice, the local authority can easily rezone land from rustic to potentially urban, although justification needs to be provided to the regional or national government, and forests are especially protected and difficult to rezone.

\footnotetext{
${ }^{7}$ For instance, "Ecologistas en Acción" ("Environmentalists in Action”) claim that "we cannot ignore the fact that most forest fires taking place in Spain are intentional, mostly with urbanization purposes or caused by negligence." (translation by the author, see http://www.ecologistasenaccion.org/article.php3?id_article=2663).

${ }^{8}$ The Spanish Forest Fires Department reports in its webpage that although "the media routinely blames forest fires on urbanization attempts", no hard evidence has been provided in support of this theory, suggesting that the issue should be investigated in more depth (see http://www.incendiosforestales.org/furbana.htm).
} 
Regarding the actual use of land, it is officially classified into urban land, forest, agricultural land, or pastures. Thus, land classified as potentially urban or rustic by the local authorities can in practice have one of three different uses at a given point in time (agricultural, forest or pasture). For instance, a given plot of land may be classified as potentially urban while currently being used as pasture.

Unfortunately, there are no reliable data sources that provide urban, potentially urban and rustic land area by region and over time, but there are official statistics on land area by actual use (urban, forest, agricultural or pasture).

\subsection{The construction sector and housing prices}

Housing prices have been increasing rapidly in Spain since the mid-1990's. The average price of a square meter of housing increased 151 percent between 1995 and 2005, or an average of 10 percent a year (after overall inflation has been factored in). This rise is thought to have been mostly demand-driven, ${ }^{9}$ and has been accompanied by intense construction activity. In 2004, 509,000 new dwellings were built, compared with 228,000 in 1991.

The share of residential construction in total construction in Spain (54\% in 1992) is the highest among all OECD countries (Bover and Velilla, 2002). In addition, new dwellings (and improvements) account for most (96\%) of residential construction. The procedure for

\footnotetext{
${ }^{9}$ See Bover (1993) for an analysis of the determinants of housing prices in Spain for the period 1976-1991 and García-Montalvo (2001) for a study on the period 1987-1998. They conclude that increasing per capita income can account for a large fraction of the rise in prices, with low interest rates also playing an important role.
} 
building and selling new housing in Spain is the following: builders or developers first buy the land, then they build (or sub-contract) dwellings, and then they offer the finished product for sale.

Figure 2 shows the evolution of the average price of a square meter of housing between 1995 and 2005, at the national level. In the first quarter of 1995, the average price of a house was 670 euros per square meter, compared with 1,685 in the first quarter of 2005.

The sustained increase in prices, however, has not taken place uniformly. Some regions have experienced much faster increases than others. The smallest increase in the price of new housing, in percentage terms, during the ten-year period was 58 percent (in Ourense), while in Malaga prices increased by 300 percent during the same period. A new house in Malaga was sold at 2,151 euros per square meter in the first quarter of 2005, compared with 1,032 euros in Ourense. Thus the profitability of residential construction activity varied widely across regions, given that construction costs differed only slightly. ${ }^{10}$

\section{Data and Methodology}

The analysis proceeds in two steps. First, we show that economic activity in general and the profitability of construction activity in particular affected the incidence of forest fires. Then we show that the incidence of forest fires led to changes in the use of land from (more heavily protected) forest area to urban land (where building activity takes place).

If forest fires are being used as a means to induce rezoning, it is reasonable to expect that there would be a relationship between the profitability of building activities in an area

\footnotetext{
${ }^{10}$ Garcia-Montalvo (2001) finds that construction costs are not significant in explaining the regional variation in house prices in Spain.
} 
and the incidence of forest fires. In order to test this hypothesis, I collect data at the regional level (there are 50 provinces in Spain) on economic activity, housing prices and the incidence of forest fires between 1991 and 2005.

The Ministry of the Environment publishes data on the yearly number of forest fires and the land area damaged by fire by region from 1991 to $2005 .{ }^{11} \mathrm{I}$ also collect information on regional economic activity, measured by total population and per capita GDP, from the National Statistical Office. ${ }^{12}$

In order to measure more directly the pressure on the supply of land created by an increased demand for residential construction, I also collect data on the price of the square meter of housing by region. The Ministry of Housing (2007) publishes quarterly housing prices by province (an aggregate index as well as separate prices for new construction and houses more than 2 years old) from 1995 to $2005,{ }^{13}$ while Sociedad de Tasación (2007) provides biannual data from 1986 to $2007 .{ }^{14}$ See García-Montalvo (2001) for a discussion of these alternative data sources for house prices.

Of course, in order to capture the causal effect of economic activity and house prices on the incidence of forest fires, we need to account for other factors that may affect forest fires and at the same time be correlated with economic activity. One set of such factors may be

${ }^{11}$ See http://www.mma.es/portal/secciones/biodiversidad/defensa_incendios/estadisticas _incendios/.

${ }^{12}$ See http://www.ine.es.

${ }^{13} \mathrm{See}$ http://www.mviv.es/es/index.php?option=com content\&task=view \&id=66\& $\underline{\text { Itemid }=106 .}$

${ }^{14} \mathrm{See}$ http://web.st-tasacion.es/html/index.php. 
geographical, such as the regional climate and the geological features of the land. I account for these factors through the inclusion of region fixed effects. There could also be unobserved factors that vary over time, such as periods of drought affecting both economic patterns and wildfires, or changes in national fire prevention or extinction policies. We thus also include year fixed effects. Our main specification is the following:

$[1] \quad F_{i t}=\alpha+\beta P_{i t}+\not N_{i t}+\delta_{1} G D P_{i t}+\delta_{2} G D P_{i t}^{2}+\mu_{i}+\lambda_{t}+\varepsilon_{i t}$

Where $i$ indexes regions, $t$ is the year, $F$ is a measure of the incidence of forest fires (such as the number of blazes or the surface burned), $P$ is an index for the price of housing, $N$ is total population in the region, and GDP is the per capita gross domestic product of the region.

The combined data set, then, includes forest fire variables, house prices, population and GDP data by region between 1991 and $2004 .^{15}$ The number of observations is 700 (50 provinces times 14 years). The price variables reflect house prices in December of the previous year, or the first quarter of a given year (depending on which of the two price sources we use), while the forest fire variables refer to all fires that took place during the whole (subsequent) year.

The model is estimated for six different dependent variables that provide alternative measures of the incidence of forest fires: total number of blazes, number of small blazes (less than 2.5 acres affected), number of large blazes, total surface affected, tree area affected, and non-tree area affected.

Once it is established that economic activity affects the incidence of forest fires, I turn to demonstrate that forest fires have a direct influence on the use of land. Thus I also collect

\footnotetext{
${ }^{15}$ Or 1995-2004, depending on the source used for house prices.
} 
data on the uses of land in each region and over time, where land is classified as either agricultural, pasture, forested, or urban. ${ }^{16}$ Obviously, economic activity can affect the use of land directly and not only through forest fires, thus all the economic activity indicators are included as controls. In particular, we allow housing prices to have a direct effect on the use of land. We also account for unobserved region-specific characteristics through region fixed effects, and allow for time-varying factors (such as legal changes at the national level) that are common to all regions through year dummies. The second-step specification is thus:

[2] $L_{i j t}=\alpha_{j}+\rho_{j} F_{i t-1}+\beta_{j} P_{i t}+\gamma_{j} N_{i t}+\delta_{1 j} G D P_{i t}+\delta_{2 j} G D P_{i t}^{2}+\mu_{i j}+\lambda_{j t}+\varepsilon_{i j t}$

Where $j$ indexes the four different uses of land and $L$ measures the land area (in hectares) corresponding to each type of land use every year. Note that equation 2 actually denotes four separate regressions, one for each use of land $(j)$. We are interested in the four coefficients $\rho_{j}$, which measure the rate at which an acre of forest affected by wildfire remains classified as forest area in subsequent years or gets converted into other uses of land. Note that the four $\rho_{j}$ coefficients always sum up to zero. For instance, if forest fires did not affect the use of land, all four coefficients would equal zero. At the other extreme, if each acre damaged by fire was converted into urban land, the coefficient would be -1 in the forest land area regression and 1 in the urban land one.

We estimate the four regressions jointly as seemingly unrelated regressions (Zellner, 1962) to account for the fact that the four uses of land must sum up to total land area, and thus the error terms in the four regressions are bound to be correlated. We also estimate additional specifications where we add further lags of the incidence of forest fires

${ }^{16}$ Source: Spanish National Statistical Institute (www.ine.es). 
measures, to account for the possibility that it may take more than one year to change the use of land.

\section{Results}

\subsection{Economic activity and the incidence of forest fires}

Table 2 shows some descriptive statistics for the two samples used to estimate equation 1. The first sample, using data on house prices in the main city of each region (from Sociedad de Tasación), spans from 1991 to 2004 , thus the number of observations is $700 .{ }^{17}$ The second sample uses data on average house prices in each region from the Ministry of Housing and is restricted to the period 1995 to 2004, leading to a smaller sample size of 500. ${ }^{18}$ The average price of the square meter in the main city of each region between 1991 and 2004 was 900 euros, while average price in the region over the 1995-2004 period was 782 euros, with a large variance across regions.

Between 1991 and 2004, on average almost 3,000 hectares a year were affected by wildfire in each region, resulting from almost 400 blazes. Average population in each region was about 800,000 inhabitants, and per capita GDP reached on average 12,260 euros, also with large dispersion across regions.

Table 3 reports the results from estimating equation 1 for two different measures of the incidence of forest fires: total number of blazes and total land area affected by fire. Columns 1 to 3 use the longer sample, while columns 4 to 6 use the 1995-2004 subsample with the alternative house price variable. All specifications include year dummies. Columns

\footnotetext{
${ }^{17}$ The data on house prices refer to the month of December of the previous year.

${ }^{18}$ In this case, the data on house prices refer to the first quarter of each year.
} 
1 and 4 display the coefficients from random effects estimation, while the rest present the region fixed effect results. In addition, columns 3 and 6 include region-specific linear trends. The preferred specifications are shown in columns 2 and 3 (full sample with region fixed effects).

Note that total population in a region does not appear to be a significant determinant of the incidence of forest fires for either of the two dependent variables, and the sign changes across specifications. Per capita GDP and its square are significant in specification 3 for land area affected by forest fires. This pattern suggests an inverse U-shaped relationship between income and the incidence of forest fires, i.e. as per capita GDP increases in a region, the incidence of forest fires rises, but after a certain income threshold, the sign of the relationship is reversed.

However, our focus here is on a specific source of income growth: that associated with construction activity. House prices are included as a proxy for the profitability of residential construction activity in a region. The estimated effect of house prices on the incidence of forest fires is positive in all specifications, and often statistically significant, especially in the specifications for number of fires. The magnitude of the effect suggests that a 3-euro increase in the price of the square meter leads to one extra fire per year in the region, or about 10 extra hectares affected by forest fires.

Note that these results are unlikely to be driven by endogeneity bias. The region fixed effects account for unobserved region-specific heterogeneity, and the controls for population and per capita GDP account for overall changes in economic activity across regions and over time.

One may think that the incidence of forest fires has a direct impact on house prices, since deforestation may reduce the environmental quality of the region, thus making the 
location less attractive and reducing the demand for housing. However, note that this source of reverse causality would generate a negative correlation between house prices and forest fires, thus our results can be thought of as underestimating the causal effect of housing prices on the incidence of forest fires. Note also that the timing of the variables at least partially corrects for possible reverse causality (the price data are lagged with respect to the incidence of forest fires over the following year).

Additional specifications are estimated that include population squared as a control, which is typically not significant. Also, we estimate separate specifications for the four additional measures of the incidence of forest fires: the number of small and large blazes, and the tree area affected versus non-tree area affected. ${ }^{19}$ The results suggest that the effect of house prices on the incidence of forest fires takes place through an increase in the number of small blazes that affect both tree and non-tree area.

\subsection{Forest fires and land use}

Next we estimate the set of four regressions described by equation 2, where the four dependent variables correspond to the four alternative uses of land (forest, urban, agricultural or pastures). The data on land use spans from 1992 to 2003, thus the sample size is now 600. On average, forest area was 327,270 hectares (about 810,000 acres) per region (see table 4), slightly less than the land area dedicated to agricultural activity and twice the size of urban land area.

The models for changes in land use in a region include the same controls as the previous specifications (population and per capita GDP), as well as measures of the

\footnotetext{
${ }^{19}$ These results are available upon request.
} 
incidence of forest fires during the previous year (both total number of fires and total land area affected by forest fires). Housing prices are also included since they may have a direct effect in addition to the indirect one through inducing forest fires. For instance, increases in the demand for housing in a region may lead to a direct rezoning of some forest area for residential construction purposes.

First I report the results of the deforestation regressions, i.e. the specifications where I estimate the extent to which the incidence of forest fires leads to a reduction in the land area classified as forest the following year. The main results are displayed in table 5. There appears to be a negative although weakly significant relationship between total population and forest area, as one may have expected. There is also some evidence suggesting that income growth leads to deforestation (see specification 3). House prices, on the other hand, don't seem to have a direct significant association with deforestation, although the sign tends to be positive, possibly reflecting reverse causality.

The most consistent result shows that more land area affected by forest fire the previous year leads to deforestation, i.e. a significant reduction in forest area the following year. Each acre affected by wildfire leads to a subsequent drop in forest area of 0.4 to 0.8 acres of land. $^{20}$

These changes in the use of land could imply a corresponding increase in agricultural land, urban land, or pastures. Since our goal is to test whether forest fires are induced in order to rezone forest land as urban, Table 6 shows the effect of the incidence of forest fires

\footnotetext{
${ }^{20}$ Additional specifications are estimated adding second lags for both measures of the incidence of forest fires. The second lags are never statistically significant. These results are available upon request.
} 
on urban land area in subsequent years. The results suggest that the decrease in forest land area following a forest fire translates almost one to one into increases in urban land, i.e. land where building activity takes place. Results are reported for specifications that include one and two lags for the incidence of forest fires. Both lags are significant in the preferred specification (column 4). Each acre of land damaged by a forest fire leads to a significant increase in urban land of 0.6 to 0.7 acres the following year, and 0.2 to 0.4 additional ones the year after.

Finally, table 7 shows the effect of the incidence of forest fires on the remaining two alternative uses of land. There is a small (and usually insignificant) negative effect of forest fires on agricultural land area, and this seems to be mirrored by a by a small increase in pastures.

\section{Conclusions}

The results provide evidence suggesting that the combination of land-use restrictions and an increasing demand for housing can generate incentives to induce forest fires as a means to circumvent regulation and increase the supply of land available for residential construction. This is one so-far unexplored channel through which economic activity can generate environmental hazards.

The media in different countries often report the suspicion that the recent increase in the incidence of forest fires may be driven by arson committed by property speculators trying to build on forest land. These reports have been particularly common in recent years in Mediterranean countries, where rising incomes have fuelled a construction boom that has certainly generated strong economic incentives for arsonists. However, these suspicions 
have never been backed by hard evidence. This paper is the first to attempt an empirical test of such claims.

I collect official data on the yearly incidence of forest fires by region in Spain between 1991 and 2004. I also construct series of the price of housing by region during the same period. I then estimate the effect of the price of new housing on the incidence of forest fires by province, including controls for economic activity, year dummies and region fixed effects. The results suggest that higher house prices in a region lead to an increase in the incidence of forest fires. The effect is significant and its magnitude is not negligible: an increase in the price of housing of one standard deviation (360 euros) leads to an additional 120 fires a year in a province (for a mean of 389), affecting 4,000 acres (for an average of $7,400)$.

I also collect official data on the use of land, and find that forest fires indeed lead to a reduction in forest area and a subsequent increase in urban land area, where residential construction takes place. In particular, each acre affected by forest fire leads to a decrease of about 0.8 acres in forest area the following year, and a corresponding increase in urban land area.

These findings suggest that policy makers should take into account the potential perverse incentives generated by land-use regulation. One example can be found in the countries that restrict the rezoning of forest land for a number of years after the area is affected by wildfire, thus limiting the appeal of fire as a means to increase the supply of available land for residential use. Greek law, for instance, states that builders cannot put up homes on former forested areas. The Italian government passed a law in 2000 banning 
construction for 15 years on property where there had been a blaze, and under a 2006 Spanish law, land use cannot be changed for 30 years after a forest fire. ${ }^{21}$

However, the effectiveness of such laws may be limited and thus additional measures may need to be implemented. Media reports suggest that "developers are practiced at getting around such regulations." ${ }^{22}$ There are also implementation issues: the recent Italian legislation, for instance, has to be adopted at the local level, and many municipalities have not done so. ${ }^{23}$ A recent surge in blazes in Greece led the prime minister to promise stricter measures, such as taking satellite photos regularly to help enforce the law banning construction on forest areas. Similar measures have been proposed by the Spanish government. A useful avenue for future research would analyze the effectiveness of different sets of policies at preventing arson by speculators trying to build on forest land.

\footnotetext{
${ }^{21}$ See "A combustible mixture" (The Economist, August 30th 2007) and "Smoke gets in their eyes" (The Economist, August 4th 2007). 22 "A combustible mixture" (The Economist, August 30th 2007). 23 "A combustible mixture" (The Economist, August 30th 2007).
} 


\section{References}

Bover, O. and P. Velilla (2002) "Hedonic House Prices Without Characteristics: The Case of New Multiunit Housing" CEPR Discussion Paper no. 3161.

Bover, O. (1993)"An Empirical Model of House Prices in Spain (1976-1991)" Investigaciones Económicas, 17, pp. 65-86.

Copeland, B. R. and M. S. Taylor (2004) "Trade, Growth and the Environment." Journal of Economic Literature, 42(1), pp. 7-71.

García-Montalvo (2001) "Un análisis empírico del crecimiento del precio de la vivienda en las Comunidades Autónomas españolas," Revista Valenciana de Economía y Hacienda, 2, pp. 117-136.

Grossman, G. M. and A. B. Krueger (1995) The Quarterly Journal of Economics, 110(2), pp. 353-377.

Instituto Nacional de Estadística (2007) (http://www.ine.es/).

Koop, G. and L. Toole (1999) "Is there an environmental Kuznets curve for deforestation?" Journal of Development Economics 58, pp. 231-244.

Shafik, N. (1994) "Economic Development and Environmental Quality: An Econometric Analysis." Oxford Economic Papers, New Series, 46, Special Issue on Environmental Economics, pp. 757-773.

Sociedad de Tasación (2007) "Precios de la Vivienda" (http://web.sttasacion.es/html/menu6.php).

Spanish Ministry of the Environment (2007) "Los incendios forestales en España" (http://www.mma.es/portal/secciones/biodiversidad/defensa_incendios/estadisticas_incendi $\underline{\mathrm{os}} /$. 
Spanish Ministry of Housing (2007) "Precios de Vivienda" (http://www.mviv.es/es/ index.php?option=com_content\&task=view\&id=66\&Itemid=106).

Zellner, A. (1962)"An efficient method of estimating seemingly unrelated regression equations and tests for aggregation bias." Journal of the American Statistical Association 57, pp. 348-368. 
Figure 1. Yearly number of forest fires in Spain, 1961-2005 (in thousands).

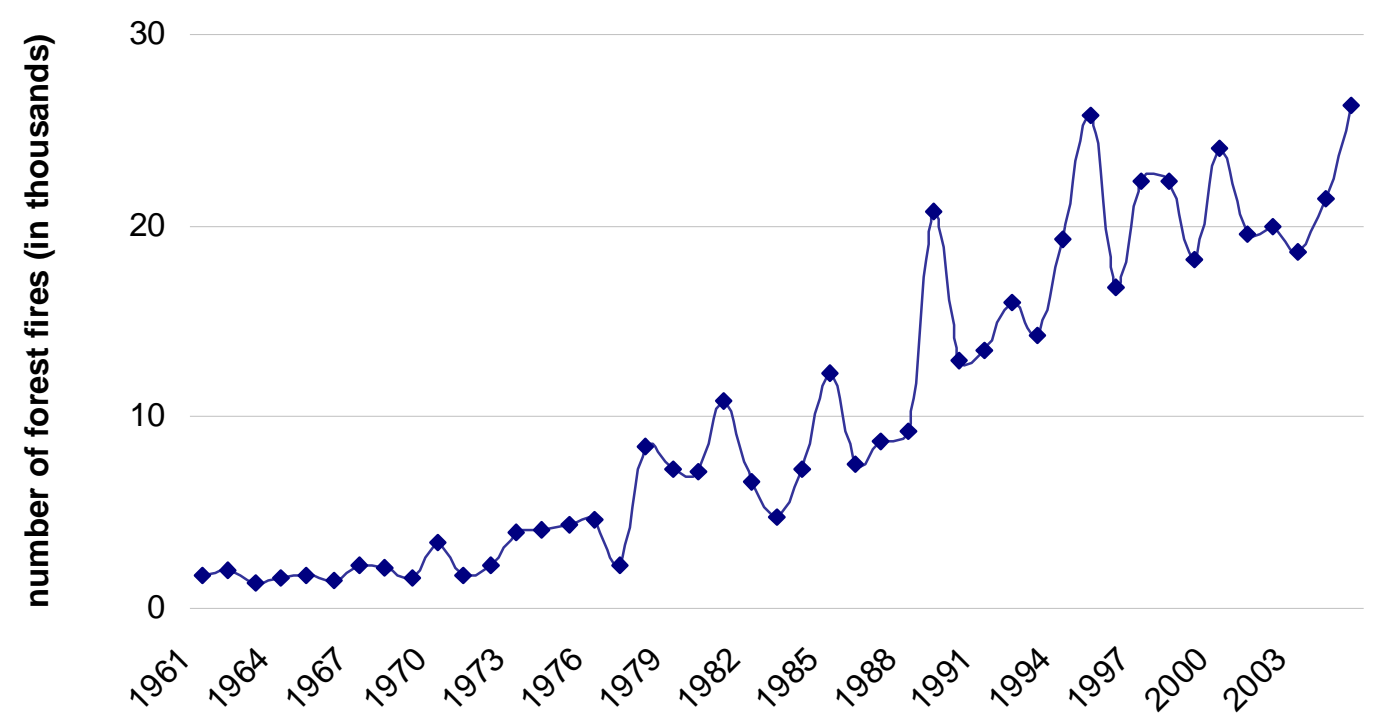

Source: Spanish Ministry of the Environment (http://www.mma.es). 
Figure 2. Quarterly average price of a square meter of housing, Spain, 1995-2005

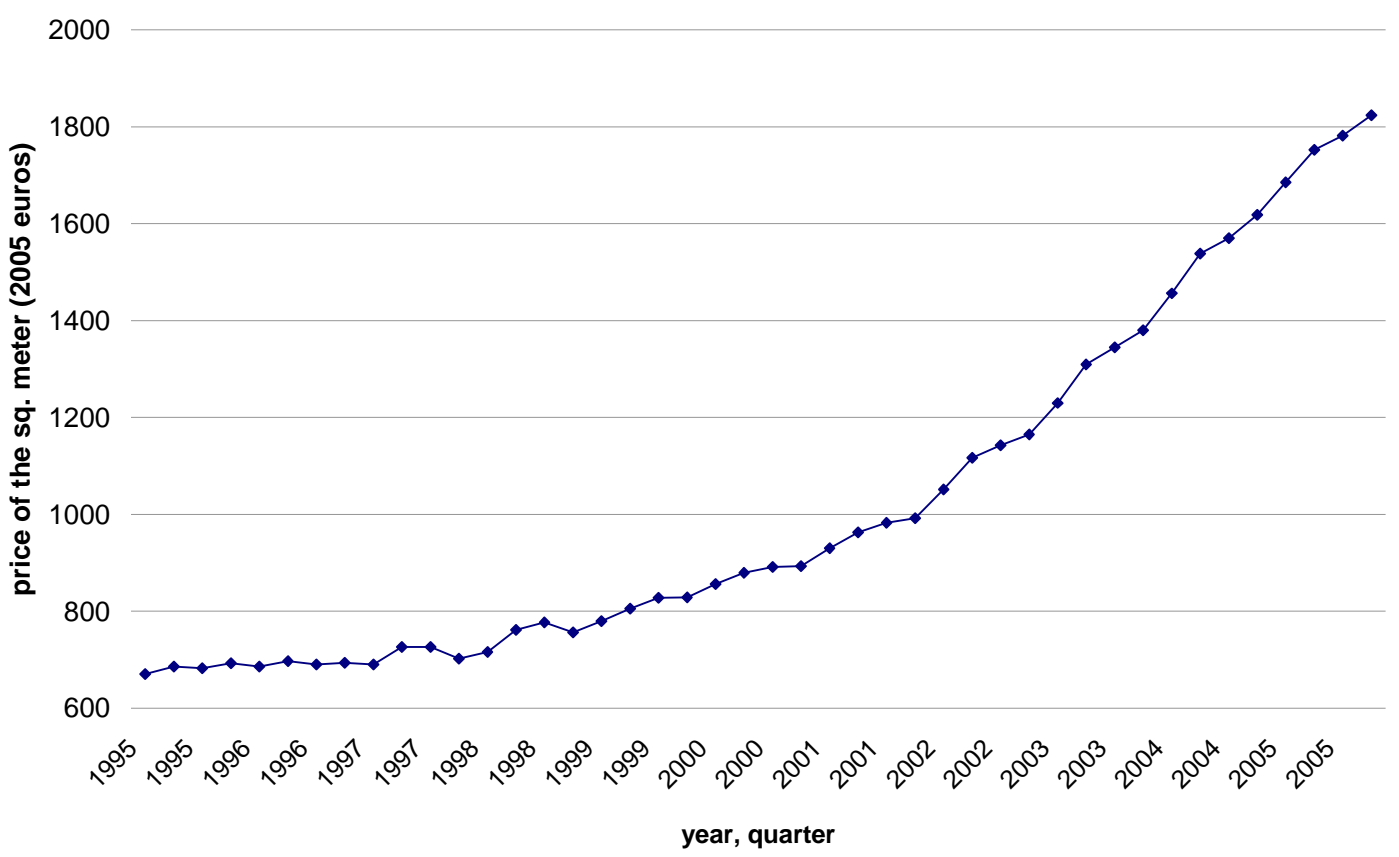

Source: Spanish Ministry of Housing. Prices are expressed in 2005 euros. (http://www.mviv.es). 
Table 1. International incidence of forest fires (1991-2004 yearly average)

\begin{tabular}{|c|c|c|c|c|c|c|}
\hline & Europe & $\begin{array}{l}\text { US+ } \\
\text { Canada }\end{array}$ & Spain & Italy & Greece & Portugal \\
\hline Number of blazes & 94,012 & 126,577 & 19,449 & 9,544 & 3,743 & 24,655 \\
\hline $\begin{array}{l}\text { Number of blazes } \\
\text { per } 10,000 \text { ha }\end{array}$ & & & 7.18 & 11.55 & 5.32 & 83.33 \\
\hline $\begin{array}{l}\text { Land area affected } \\
\text { (acres) }\end{array}$ & $1,325,355$ & $8,565,341$ & 362,553 & 242,551 & 119,325 & 320,602 \\
\hline $\begin{array}{l}\text { Percent of forest area } \\
\text { affected }\end{array}$ & & & 0.54 & 1.21 & 0.69 & 4.39 \\
\hline
\end{tabular}

Source: Spanish Environment Ministry

(http://www.incendiosforestales.org/estadisticas.htm).

Note: The averages for Europe and US+ Canada correspond to the 1991-2001 period. 
Table 2. Summary Statistics, Incidence of Forest Fires Regressions

a) 1991-2004 Sample

\begin{tabular}{lccccc}
\hline Variable & N & Mean & Std. Dev. & Min & Max \\
\hline Total land area affected (in ha.) & 700 & 2,973 & 6,349 & 0 & 84,660 \\
Tree area affected (in ha.) & 700 & 1,111 & 3,517 & 0 & 52,264 \\
Total number of fires & 700 & 389 & 748 & 0 & 5,317 \\
Number of small blazes & 700 & 235 & 527 & 0 & 4,067 \\
Number of large blazes & 700 & 150 & 270 & 0 & 2,059 \\
Average price of sq. meter of & 700 & 900 & 360 & 391 & 2,917 \\
housing (in euros) & 700 & 813.98 & 970.44 & 90.91 & $6.0 \mathrm{e}+03$ \\
Population (in thousands) & 700 & 12.26 & 3.87 & 5.23 & 25.80 \\
Per capita GDP (in 1,000 euros) & & & &
\end{tabular}

Note: The number of observations is 700 (50 provinces times 14 years). The total number of fires equals the number of small blazes, plus the number of large blazes, plus the number of reproductions. The price of housing refers to December of the previous year.

b) 1995-2004 Sample

\begin{tabular}{lccccc}
\hline Variable & N & Mean & Std. Dev. & Min & Max \\
\hline Total land area affected (in ha.) & 500 & 2,373 & 4,520 & 0 & 35,691 \\
Tree area affected (in ha.) & 500 & 673 & 1,591 & 0 & 18,047 \\
Total number of fires & 500 & 418 & 825 & 0 & 5,317 \\
Number of small blazes & 500 & 259 & 579 & 0 & 4,067 \\
Number of large blazes & 500 & 154 & 292 & 0 & 2,059 \\
Average price of sq. meter of & 500 & 782 & 329 & 376 & 2,298 \\
housing (in euros) & 500 & 824.55 & 986.36 & 90.91 & $6.0 \mathrm{e}+03$ \\
Population (in thousands) & 500 & 13.65 & 3.56 & 6.34 & 25.80 \\
Per capita GDP (in 1,000 euros) & & & & &
\end{tabular}

Note: The number of observations is 500 (50 provinces times 10 years). The total number of fires equals the number of small blazes, plus the number of large blazes, plus the number of reproductions. The price of housing refers to the first quarter of each year. 
Table 3. Regression Results, Incidence of Forest Fires

a) Dependent variable: Total number of forest fires

\begin{tabular}{|c|c|c|c|c|c|c|c|c|}
\hline & 1 & & 2 & & 3 & 4 & 5 & 6 \\
\hline Housing price & $\begin{array}{c}0.3167 \\
(0.1330)\end{array}$ & $* *$ & $\begin{array}{c}0.3393 \\
(0.1375)\end{array}$ & $* *$ & $\begin{array}{c}0.3262 \\
(0.2507)\end{array}$ & $\begin{array}{c}0.1899 \\
(0.1324)\end{array}$ & $\begin{array}{c}0.1804 \\
(0.1428)\end{array}$ & $\begin{array}{c}0.1070 \\
(0.2470)\end{array}$ \\
\hline Population & $\begin{array}{l}-0.0814 \\
(0.0934)\end{array}$ & & $\begin{array}{l}-0.2190 \\
(0.1951)\end{array}$ & & $\begin{array}{c}0.5120 \\
(0.4934)\end{array}$ & $\begin{array}{c}0.013 \\
(0.1032)\end{array}$ & $\begin{array}{c}0.0705 \\
(0.2196)\end{array}$ & $\begin{array}{l}-0.1448 \\
(0.5815)\end{array}$ \\
\hline Pc GDP & $\begin{array}{c}14.52 \\
(38.41)\end{array}$ & & $\begin{array}{c}39.67 \\
(43.04)\end{array}$ & & $\begin{array}{c}12.76 \\
(67.10)\end{array}$ & $\begin{array}{l}-95.56 \\
(50.17)\end{array}$ & $\begin{array}{ll}* & -61.31 \\
& (61.67)\end{array}$ & $\begin{array}{c}64.95 \\
(118.27)\end{array}$ \\
\hline Pc GDP sq. & $\begin{array}{l}-1.439 \\
(0.972)\end{array}$ & & $\begin{array}{l}-1.870 \\
(1.044)\end{array}$ & * & $\begin{array}{l}-0.5149 \\
(2.2687)\end{array}$ & $\begin{array}{c}1.431 \\
(1.165)\end{array}$ & $\begin{array}{c}0.8938 \\
(1.3121)\end{array}$ & $\begin{array}{l}-2.661 \\
(3.771)\end{array}$ \\
\hline $\mathrm{N}$ & 700 & & 700 & & 700 & 500 & 500 & 500 \\
\hline $\begin{array}{l}\text { Year dummies? } \\
\text { Region fixed }\end{array}$ & $Y$ & & $Y$ & & $Y$ & $Y$ & $Y$ & $Y$ \\
\hline $\begin{array}{l}\text { effects? } \\
\text { Region-specific }\end{array}$ & $\mathrm{N}$ & & $Y$ & & $Y$ & $\mathrm{~N}$ & $N$ & $Y$ \\
\hline $\begin{array}{l}\text { trends? } \\
\text { Within } R^{2}\end{array}$ & $\begin{array}{c}\mathrm{N} \\
0.0762\end{array}$ & & $\begin{array}{c}\mathrm{N} \\
0.0780\end{array}$ & & $\begin{array}{c}Y \\
0.2251\end{array}$ & $\begin{array}{c}\mathrm{N} \\
0.0656\end{array}$ & $\begin{array}{c}\mathrm{N} \\
0.0664\end{array}$ & $\begin{array}{c}Y \\
0.2826\end{array}$ \\
\hline Between $R^{2}$ & 0.0198 & & 0 & & 0.6122 & 0.0786 & 0.0412 & 0.5729 \\
\hline
\end{tabular}

b) Dependent variable: Total surface affected by forest fires (in ha.)

\begin{tabular}{|c|c|c|c|c|c|c|c|c|}
\hline & 1 & 2 & & 3 & & 4 & 5 & 6 \\
\hline \multirow[t]{2}{*}{ Housing price } & 1.923 & 4.537 & * & 1.5814 & & 1.566 & 1.539 & 3.724 \\
\hline & $(1.952)$ & $(2.706)$ & & $(4.9801)$ & & $(1.573)$ & (1.941) & $(3.467)$ \\
\hline \multirow[t]{2}{*}{ Population } & 0.1339 & -6.0950 & & 10.1998 & & -0.0364 & 0.2745 & -8.2400 \\
\hline & $(0.5470)$ & (3.8378) & & $(9.8011)$ & & $(0.4934)$ & $(2.9867)$ & $(8.1630)$ \\
\hline \multirow[t]{2}{*}{ Pc GDP } & 121.82 & 1350.4 & & 3367.3 & $* *$ & -45.33 & 652.59 & 1115.3 \\
\hline & $(470.78)$ & (852.30) & & (1372.66) & & $(423.88)$ & $(838.61)$ & $(1660.10)$ \\
\hline \multirow[t]{2}{*}{ Pc GDP sq. } & -16.81 & -40.51 & $* *$ & -116.4 & $* * *$ & -13.14 & -24.22 & -48.29 \\
\hline & $(15.06)$ & (20.54) & & $(45.07)$ & & $(12.70)$ & (17.84) & (52.94) \\
\hline$N$ & 700 & 700 & & 700 & & 500 & 500 & 500 \\
\hline Year dummies? & $Y$ & Y & & $Y$ & & Y & Y & Y \\
\hline $\begin{array}{l}\text { Region fixed } \\
\text { effects? }\end{array}$ & $\mathrm{N}$ & $Y$ & & $Y$ & & $\mathrm{~N}$ & Y & Y \\
\hline $\begin{array}{l}\text { Region-specific } \\
\text { trends? }\end{array}$ & $\mathrm{N}$ & $\mathrm{N}$ & & Y & & $\mathrm{N}$ & $\mathrm{N}$ & Y \\
\hline Within $\mathrm{R}^{2}$ & 0.1204 & 0.1301 & & 0.2545 & & 0.0592 & 0.0610 & 0.2312 \\
\hline Between $R^{2}$ & 0.1005 & 0.0277 & & 0.1743 & & 0.1200 & 0.0040 & 0.1481 \\
\hline
\end{tabular}

Note: The first 3 columns include 1991 to 2004 and use house price data from Sociedad de Tasación, the remaining 3 include 1995 to 2004 and use data on house prices from the Ministry of Housing. One asterisk indicates significance at the $90 \%$ confidence level, two indicate $95 \%$ and three, $99 \%$. 
Table 4. Descriptive Statistics, Use of Land Regressions, 1992-2003 Sample

\begin{tabular}{lccccc}
\hline Variable & N & Mean & Std. Dev. & Min & Max \\
\hline Forest area (hectares) & 600 & 327,270 & 178,224 & 11,506 & 947,338 \\
Agricultural land area (ha) & 600 & 372,769 & 283,615 & 2,792 & $1.1 \mathrm{e}+06$ \\
Urban land area (ha) & 600 & 169,687 & 108,400 & 16,294 & 554,146 \\
Pastures (ha) & 600 & 139,783 & 121,447 & 0 & 582,753 \\
Land area affected by fire (1 lag) & 600 & 3,008 & 6,560 & 0 & 84,660 \\
Number of fires (1 lag) & 600 & 387 & 757 & 0 & 5,317 \\
Total land area of the province & 600 & 10,092 & 4,762 & 1,909 & 21,766 \\
Population (in 1000) & 600 & 811.79 & 965.47 & 90.91 & $5.8 \mathrm{e}+03$ \\
Per capita GDP (in 1000 euros) & 600 & 12.19 & 3.59 & 5.58 & 24.38 \\
\hline
\end{tabular}

Note: The number of observations is 600 (50 provinces times 12 years). The total number of fires equals the number of small fires, plus the number of large fires, plus the number of reproductions. 
Table 5. Regression Results, Dependent Variable Forest Area

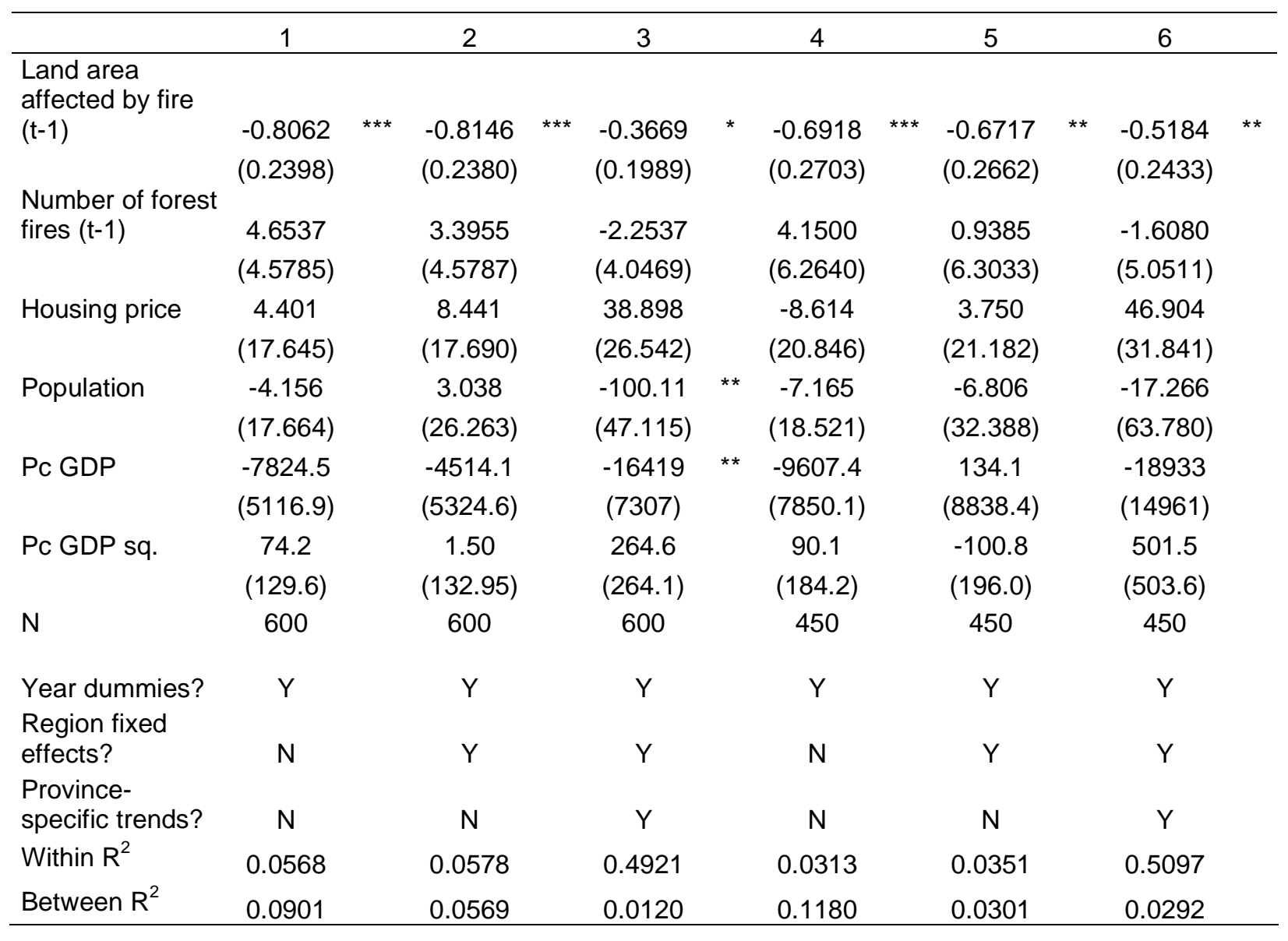

Note: The first three columns include 1992 to 2004 and use house price data from Sociedad de Tasación, the remaining 3 include 1996-2004 and use data on house prices from the Ministry of Housing. One asterisk indicates significance at the $90 \%$ confidence level, two indicate $95 \%$ and three, $99 \%$. 
Table 6. Regression Results, Dependent Variable Urban Land Area

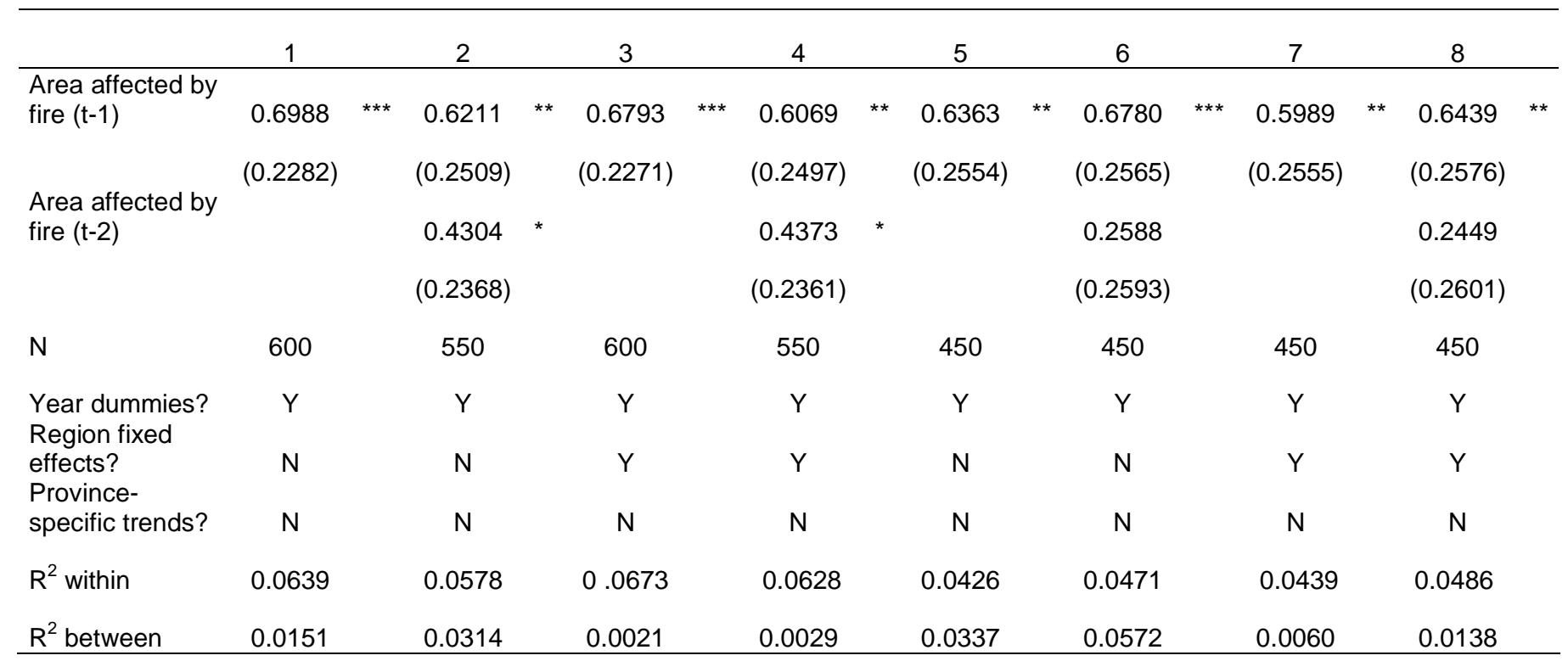

Note: The first four columns include 1992 to 2004 and use house price data from Sociedad de Tasación, the remaining four include 1996-2004 and use data on house prices from the Ministry of Housing. One asterisk indicates significance at the $90 \%$ confidence level, two indicate $95 \%$ and three, $99 \%$. 
Table 7. Regression Results, Other Uses of Land

\begin{tabular}{|c|c|c|c|c|c|c|c|}
\hline Dep. var. & 1 & 2 & 3 & & 4 & 5 & 6 \\
\hline \multirow[t]{2}{*}{ Agricultural use } & -0.0064 & -0.0166 & -0.3149 & * & -0.2595 & -0.2560 & -0.1399 \\
\hline & $(0.1977)$ & $(0.1946)$ & $(0.1860)$ & & $(0.1865)$ & $(0.1810)$ & $(0.2092)$ \\
\hline \multirow[t]{2}{*}{ Pastures } & 0.1776 & 0.1641 & 0.3918 & $* *$ & 0.3241 & 0.3449 & * 0.3598 \\
\hline & $(0.2107)$ & $(0.2112)$ & $(0.1931)$ & & $(0.2090)$ & $(0.2081)$ & $(0.2282)$ \\
\hline $\mathrm{N}$ & 600 & 600 & 600 & & 450 & 450 & 450 \\
\hline Year dummies? & $\mathrm{Y}$ & $\mathrm{Y}$ & $\mathrm{Y}$ & & $\mathrm{Y}$ & $\mathrm{Y}$ & $Y$ \\
\hline $\begin{array}{l}\text { Region fixed } \\
\text { effects? } \\
\text { Province- }\end{array}$ & $\mathrm{N}$ & Y & Y & & $\mathrm{N}$ & Y & Y \\
\hline specific trends? & $\mathrm{N}$ & $\mathrm{N}$ & Y & & $\mathrm{N}$ & $\mathrm{N}$ & $\mathrm{Y}$ \\
\hline
\end{tabular}

Note: The table displays coefficients and standard errors corresponding to the explanatory variable "area affected by forest fires ( $\mathrm{t}-1)$ " from regressions where the dependent variable is indicated in the first column. The first three columns include 1992 to 2004 and use house price data from Sociedad de Tasación, the remaining three include 1996-2004 and use data on house prices from the Ministry of Housing. One asterisk indicates significance at the 90\% confidence level, two indicate $95 \%$ and three, $99 \%$. 